\title{
Examination on the Effect of Learning Strategies on Physical Education and Sports Teacher Candidates and Their Motivation of Curiosity and Levels of Exploration
}

\author{
Mehmet Behzat Turan ${ }^{1, *} \&$ Kenan Koç ${ }^{1}$ \\ ${ }^{1}$ Physical Education and Sport Department, Erciyes University, Kayseri, Turkey \\ *Correspondence: Physical Education and Sport Department, Erciyes University, 38039, Kayseri, Turkey. Tel: \\ 90-542-824-0066. E-mail: behzatturan@erciyes.edu.tr
}

Received: May 11, 2018

doi:10.5430/wje.v9n1p92
Accepted: June 12, $2018 \quad$ Online Published: February 1, 2019

URL: https://doi.org/10.5430/wje.v9n1p92

\begin{abstract}
The puropose of this study is to examine the effect of learning strategies on physical education candidates and their motivation of curiosity and levels of exploration. In accordance with this purpose, the study group is formed by the randomly chosen senior year students of Erciyes, Ömer Halisdemir, Aksaray, Dumlupınar, Gaziantep, Fırat, Selçuk, Ahi Evran, Hacı Bektaşi Veli universities' Physical Education and Sports Teacher department. Motivated Strategies for Learning Questionnaire, MSLQ (Büyüköztürk, Akgün, Özkahveci and Demirel, 2004), Curiosity and Exploration Inventory-II, CEI (Kashdan et al. 2009) and the 'Personal Information Form' which was prepared by the researcher are used in order to collect data in the research.

In order to put forth the relation between the scores that were gathered from the scales, Pearson Product-Moment Correlation Coefficient analysis (r) and to determine whether the scores that were gathered are predictive or not Multiple Regression Analysis was applied ( $\beta$ ).

From the curiosity and exploration sub dimensions, a positive significant relation is found between flexibility and motivation. Furthermore, a positive significant relation is determined between accepting the uncertainty sub-dimension and motivation. A great deal of positive relation is found between the total rates of curiosity and exploration and level of motivation. While there is a positive significant relation between the curiosity and exploration and learning strategies with flexibility, a positive significant relation between accepting the uncertainty sub-dimension and learning strategies is determined too. A positive significant relation is also found between total rates of curiosity and exploration and the use of learning strategies.
\end{abstract}

Keywords: curiosity and exploration, motivation, learning strategies

\section{Introduction}

Physical education lesson is considered to be the leading lesson in shaping the children and youth in schools to the future. Physical education lessons are not only preparing our children and youth for the future cognitively, but also cover the psychomotor developments with affective developments by providing them to be involved in life. Professional personality competencies of physical education teachers are considered to have an important role in this process. Ünlü, Sünbül and Aydos (2008) define the physical education teacher's competency as, having the necessary knowledge, understanding, skill and attitudes in order to carry out the responsibilities and duties which require to be a physical education teacher. One of the affecting elements of quality physical education lesson are the physical education teachers. Yaylac1 (2012) formulated as "Quality physical education lesson = Quality physical education teacher". In Ünlü's (2008) research, the higher the physical education teacher's vocational and personal competencies are, the better the quality of the lesson idea supports the result of displaying positive class management attitudes of physical education teachers who perceive the competency of teaching at a greater level. Mc Neil (1985) explains the competency of physical education and sports teachers' by possessing knowledge about the subject field and organizing the learning-teaching process. Among the standards that physical education teacher candidates should have are mentioned by the NASPE (National Association for Sports and Physical Education, 2008): teachers should provide individual and group motivation for students, should know concepts of the field and should plan and apply 
the teaching strategies according to national standards. At this point, the importance of motivation levels and learning strategies of physical education teacher candidates' are revealed.

The leading learning difficulties that students emphasize the most while they are learning, has increased the importance of learning strategies in education (Açıkgöz, 2007). In the learning process, there are different types of ways and methods that every human use as a prior. The aim of learning strategies is to ease the student's affective state and to organize the selection and to integrate the new information (Harmanl, 2000). Students' motivation level and the usage of appropriate learning strategies in proper situation plays a key role in succeeding throughout their academic lives (Garcia \& Pintrich, 1996). According to these studies, the common point can be summarized as a person's active participation in the learning process in learning strategies for actualizing consciously the processes that required to be applied.

Motivation, however, is the whole of person's behaviors and expectations. Being motivated include the behaviors that composed as a result of desires. A motivated person is a person who integrated his/her information and beliefs with successful behaviors (Stipek, 1998). Motive forces organism to give certain reactions and learn something as a result (Selçuk, 1999). Keller explained motivation as the direction of the effort that provides student's desire to learning and an innate power (Keller, 2000; Warren, 2000).

At this point, which factors physical education teacher candidates are effected while determining motivation and learning strategies, how much curiosity and exploration emotions effect teacher candidates' motivation and learning strategies questions emerge. Nowadays, not only curiosity gained itself a seat in education psychology but also has become a center of attraction in personality psychology as a conspicuous feature (Kashdan et al., 2009). Therewithal, while the function of curiosity on an individual in short range provides learning more, exploring and focusing on a single subject, in long-range provides curiosity, information and competency. Considering these definitions, curiosity can be explained as "noticing, exposing and desiring to explore new, difficult and ambiguous incidents and the potential of dealing with the incident" (Kashdan \&d Silvia, 2009, p.368; Silvia, 2008). Many experimental and empirical researchers show that during the academic process, curiosity affects positively on creating the urge for thinking, possessing high academic performance (Eren, 2009), and being object oriented. In this context, it is determined that curiosity has a positive relationship with explaining positive feelings, self-regulation, state of general happiness and psychologically feeling well, embracing experiences, extroversion, sensitivity, positive self-conception, self-determination and ego power (Kashdan et al., 2009). When the characteristics of a life-long learner are examined, it is stated that they possess curiosity, being interested in new developments and subjects, information literacy, organization and learning skills features (Akkoyunlu, 2008). Among the cognitive and affective elements that provide life-long learning characteristics, factors such as motivation, persistence, curiosity, organizing learning are emphasized. In a way, curiosity is accepted as an igniter in the learning process and it is recommended to be approached studiously in drawing attention and raising curiosity processes (Demirel \& Coşkun, 2009).

The aim of our study is to examine the effects of curiosity and exploration levels on learning strategies and to determine how much effect it has on physical education teacher candidates' who study in the school of physical education and sports. With our study, while providing a good education to physical education teacher candidates', it is thought to lead them to be good educators and to contribute to the literature.

\section{Material and Method}

\subsection{Study Group}

This research is in relational screening model. This screening model can be defined as "research models used to find the existence and/or the degree of covariance between two or more number of variables" (Karasar, 2007).

The research carries a descriptive qualification since it will make an assessment on the motivation of curiosity and exploring levels and the effects of learning strategies with relation to demographic attributes of candidates' of teachers who are studying in the school of physical education and sports.

\subsection{Data Collection Tools}

In the research, while applying the surveys to the participants, adequate evaluation conditions were created for them by giving a long period of time, being leisure, stating the necessary explanations by the researchers. Furthermore, suitable conditions were provided for participants in order to make them feel comfortable. Data collection tools used in the research are arranged as Curiosity and Exploration Inventory-II, Motivated Strategies for Learning Questionnaire and Socio-demographic information form. 


\subsection{Forming the Voluntary Groups}

The research will be conducted on a study group. The study group is formed by the senior year students of Erciyes, Ömer Halisdemir, Aksaray, Dumlupınar, Gaziantep, Fırat, Selçuk, Ahi Evran, Hacı Bektaşi Veli universities' Physical Education and Sports Teacher department.

475 randomly chosen Physical Education and Sports Teacher students attended to this study. From the participating students, minimum 5 maximum 10 students in every university were not included in the study group since they filled the form and the inventory incomplete. As a result, a total of 421 people form the sample of the research.

Table 1. Socio-Demographic Attributes of Participants

\begin{tabular}{llll}
\hline & Variables & N & \% \\
\hline Gender & Male & 220 & 52.3 \\
& Female & 201 & 47.7 \\
Age & $18-20$ & 156 & 37.1 \\
& $21-23$ & 194 & 46.1 \\
Weekly Study & $24-26$ & 71 & 16.9 \\
Time & $1-10$ & 331 & 78.6 \\
& $11-20$ & 65 & 15.4 \\
& $21-30$ & 25 & 5.9 \\
Universities & Erciyes & 54 & 12.8 \\
& Ömer Halisdemir & 48 & 11.4 \\
& Aksaray & 45 & 10.7 \\
& Ahi Evran & 45 & 10.7 \\
& Selçuk & 46 & 10.9 \\
General Academic Not Average & 44 & 10.5 \\
& Haci Bektaş Veli & 48 & 11.4 \\
& Dumlupinar & 46 & 10.9 \\
& Firat & 45 & 10.7 \\
& Gaziantep & 134 & 31.8 \\
& $1.75-2.50$ & 205 & 48.7 \\
& $2.51-3.00$ & 71 & 16.9 \\
\hline
\end{tabular}

\subsection{Socio-demographic Information Form}

While forming the socio-demographic information form of the study, Curiosity and Exploration, Motivation and Learning strategies and Socio-demographic information forms in literature were examined and a pool created in order to examine the requested features. Afterwards, with the help of a statistician, socio-demographic information form was created. This socio-demographic information form includes 5 questions about age, sex, weekly study time, grade and grade point average in order to gain information about the participants.

\subsection{Curiosity and Exploration Inventory-II (CEI-II)}

The inventory that was developed by Kashdan et al. (2009) consists of 10 subjects and 2 sub-dimensions (flexibility and accepting the uncertainty). Confirmatory Factor Analysis (CFA) has shown that these two sub-dimensions (two sub inventories) are strongly correlated to each other $(r=.85)$. In the first three studies about the inventory, lots of psychological features that compose and distinguishing validities were examined. In the fourth study, the item-reaction distinctiveness of the inventory was examined. Some of the items of the inventory were found medium-level (1, 2, 3, 6 and 8), two items high-level (9 and 10) and three items very high-level (4, 5 and 7) distinctive. Cronbach Alfa coefficient was recorded varying between 0.75 and 0.86 in three studies. The high score that will be obtained from the total of inventory's items will state the high curiosity. There is no reverse scoring item in the inventory. Some of the items of the inventory are "I seek information as much actively as I can in new situations." and "I am a person that really likes the uncertainty of daily life.".

\subsection{Motivated Strategies for Learning Questionnaire}

Motivated Strategies for Learning Questionnaire is a Turkish translated version of Motivated Strategies for Learning Questionnaire which was developed by Pintrich, Smith, Garcia and McKeachie (1991). The adaptation was carried 
out by a team involving the researcher (Büyüköztürk, Akgün, Özkahveci, \& Demirel, 2004). Consisting of two main parts, Motivation Inventory (MI) and Learning Strategies Questionnaire (LSQ), the inventory's validity and credibility studies were made separately for the two main parts by using data which were acquired from 852 students who are studying in the second, third and senior year. After taking the expert opinion for the validity study, confirmatory and exploratory factor analyzes were applied, for the credibility, on the other hand, the significance of the difference between the average item scores of top \%27 and bottom \%27 groups was examined by using Cronbach alpha internal consistency coefficient, corrected item-total correlation and t test.

Results of the confirmatory factor analysis show that both MI and LSQ has the acceptable structural validity. When credibility results are examined (see Chart 1 ) alpha rates vary from 0,86 and 0.59 to MI, 0,75 and 0,41 for LSQ. With the results of $t$ tests that were run between the average item scores of top $\% 27$ and bottom $\% 27$, it can be understood that differences are significant for all of the items and subscale total points. These findings show that all the items and subscales in the inventory are distinguishing.

Application time varies between 20-30 minutes. Participants mark their thoughts about a statement in the inventory on a seven-point Likert type rating scale which varies between "completely wrong for me" (1) and "completely accurate for me" (7). Consisting of total 15 subscales in two separate dimensions, MSLQ has a modular structure and according to the intended use of the applicator, scores that are acquired from subscales can be used separately (Pintrich et al., 1993). A high grade from any factor of the scale indicates that student has a high level of that factor.

\subsection{Analysis of Data}

The acquired data from Personal Information Form, Curiosity and Exploration, Motivation and Learning Strategies' scale and the attained scores, were registered in SPSS 20.0 package program and analyzes were made through this program. Personal information about applicants, inventory total scores and factor scores were given by determining the frequency (f) and percentage (\%) rates. In order to put forth the relation between the scores that were gathered from the scales Pearson Product-Moment Correlation Coefficient analysis ( $r$ ) and to determine whether the scores that were gathered are predictive or not, Multiple Regression Analysis was applied ( $\beta$ ).

\section{Findings}

Table 2. Descriptive Statistic of Students Answer to the Questionnaire

\begin{tabular}{llllll}
\hline & & $\mathrm{N}$ & Minimum & Maximum & $\mathrm{X} \pm \mathrm{SD}$ \\
\hline Curiosity & Flexibility & 421 & 8.00 & 30.00 & $22.74 \pm 4.14$ \\
and & Accepting the Uncertainty & 421 & 4.00 & 20.00 & $11.57 \pm 3.31$ \\
Exploring & Curiosity and Exploring Total & 421 & 16.00 & 50.00 & $34.31 \pm 6.95$ \\
& Internal Goal Arranging & 421 & 4.00 & 28.00 & $20.40 \pm 4.70$ \\
& External Goal Arranging & 421 & 4.00 & 28.00 & $19.74 \pm 5.16$ \\
& Task Value & 421 & 6.00 & 42.00 & $31.33 \pm 6.95$ \\
Motivation & Belief of Control & 421 & 7.00 & 28.00 & $20.70 \pm 4.89$ \\
& Features About Learning and Performance & 421 & 10.00 & 56.00 & $41.33 \pm 8.73$ \\
& Exam Anxiety & 421 & 5.00 & 35.00 & $19.29 \pm 5.96$ \\
& Motivation Total & 421 & 46.00 & 204.00 & $152.82 \pm 26.87$ \\
& & & & & \\
& Repetition & 421 & 4.00 & 28.00 & $20.04 \pm 4.73$ \\
& Regulation & 421 & 4.00 & 28.00 & $19.34 \pm 4.90$ \\
& Explication & 421 & 6.00 & 42.00 & $29.18 \pm 6.62$ \\
Learning & Critical Thinking & 421 & 5.00 & 35.00 & $23.57 \pm 5.62$ \\
Strategies & Seek for Help & 421 & 4.00 & 29.00 & $18.52 \pm 4.67$ \\
& Peer Collaboration & 421 & 3.00 & 21.00 & $12.51 \pm 4.14$ \\
& Meta Cognitive & 421 & 12.00 & 82.00 & $57.39 \pm 11.39$ \\
& Effort Management & 421 & 4.00 & 28.00 & $16.92 \pm 4.29$ \\
& Time and Studying Environment & 421 & 13.00 & 54.00 & $36.41 \pm 7.18$ \\
& Learning Strategies Total & 421 & 74.00 & 328.00 & $233.90 \pm 43.05$ \\
\hline
\end{tabular}


As it can be seen in table 2, applicants average of flexibility was found 22,74, the average of accepting the uncertainty was found 11,57 and average of curiosity and exploring was found 34,31 . Furthermore, the average of internal goal arranging is 20,40 , the average of external goal arranging is 19,74 , the average of task value is 31,33 , the average of belief of control is 20,70 , the average of features about learning and performance is 41,33 , exam anxiety is 19,29 and average of total motivation is 152,82 . On the other hand, average of repetition was calculated 20,04 , average of regulation was calculated 19,34 , average of explication was calculated 29,18 , average of critical thinking was calculated 23,57 average of seeking for help was calculated 18,52, average of peer collaboration was calculated 12,51, average of metacognitive was calculated 58,39, average of effort management was calculated 16,29, average of time and studying environment was calculated 36,41, average of total learning strategies was calculated 233,90 .

Table 3. Correlation Coefficient between Curiosity and Exploring Levels and Motivation of Students

\begin{tabular}{|c|c|c|c|c|c|c|c|c|c|c|c|}
\hline & & 1 & 2 & 3 & 4 & 5 & 6 & 7 & 8 & 9 & 10 \\
\hline \multirow{3}{*}{ Flexibility $^{1}$} & $\mathrm{r}$ & 1 & & & & & & & & & \\
\hline & $\mathrm{p}$ & & & & & & & & & & \\
\hline & $\mathrm{N}$ & 421 & & & & & & & & & \\
\hline \multirow{3}{*}{$\begin{array}{l}\text { Accepting the } \\
\text { Uncertainty }^{2}\end{array}$} & $\mathrm{r}$ & $.316^{* *}$ & 1 & & & & & & & & \\
\hline & $\mathrm{p}$ & .000 & & & & & & & & & \\
\hline & $\mathrm{N}$ & 421 & 421 & & & & & & & & \\
\hline \multirow{3}{*}{$\begin{array}{l}\text { Total Curiosity } \\
\text { and Exploring }\end{array}$} & $\mathrm{r}$ & $.856^{* *}$ & $.761^{* *}$ & 1 & & & & & & & \\
\hline & $\mathrm{p}$ & .000 & .000 & & & & & & & & \\
\hline & $\mathrm{N}$ & 421 & 421 & 421 & & & & & & & \\
\hline \multirow{3}{*}{$\begin{array}{l}\text { Internal Goal } \\
\text { Arranging }^{4}\end{array}$} & r & $.425^{* *}$ & $.096^{*}$ & $.343^{*}$ & 1 & & & & & & \\
\hline & $\mathrm{p}$ & .000 & .050 & .000 & & & & & & & \\
\hline & $\mathrm{N}$ & 421 & 421 & 421 & 421 & & & & & & \\
\hline \multirow{3}{*}{$\begin{array}{l}\text { External Goal } \\
\text { Arranging }^{5}\end{array}$} & $\mathrm{r}$ & $.140^{* *}$ & .018 & $.105^{*}$ & $.462^{* *}$ & 1 & & & & & \\
\hline & $\mathrm{p}$ & .004 & .719 & .031 & .000 & & & & & & \\
\hline & $\mathrm{N}$ & 421 & 421 & 421 & 421 & 421 & & & & & \\
\hline \multirow{3}{*}{ Task Value $^{6}$} & $\mathrm{r}$ & $.370^{* *}$ & .051 & $.280^{* *}$ & $.752^{* *}$ & $.430^{* *}$ & 1 & & & & \\
\hline & $\mathrm{p}$ & .000 & .299 & .000 & .000 & .000 & & & & & \\
\hline & $\mathrm{N}$ & 421 & 421 & 421 & 421 & 421 & 421 & & & & \\
\hline Belief of & $\mathrm{r}$ & $.301^{* *}$ & .001 & $.206^{* *}$ & $.638^{* *}$ & $.393^{* *}$ & $.679^{* *}$ & 1 & & & \\
\hline Control on & $\mathrm{p}$ & .000 & .983 & .000 & .000 & .000 & .000 & & & & \\
\hline Learning ${ }^{7}$ & $\mathrm{~N}$ & 421 & 421 & 421 & 421 & 421 & 421 & 421 & & & \\
\hline Features About & $\mathrm{r}$ & $.371^{* *}$ & .087 & $.301^{* *}$ & $.737^{* *}$ & $.486^{* *}$ & $.761^{* * *}$ & $.585^{* *}$ & 1 & & \\
\hline Learning and & $\mathrm{p}$ & .000 & .073 & .000 & .000 & .000 & .000 & .000 & & & \\
\hline Performance ${ }^{8}$ & $\mathrm{~N}$ & 421 & 421 & 421 & 421 & 421 & 421 & 421 & 421 & & \\
\hline \multirow{3}{*}{ Exam Anxiety ${ }^{9}$} & $\mathrm{r}$ & .012 & $.216^{* *}$ & $.126^{*}$ & $.135^{*}$ & $.243^{* *}$ & $.114^{* *}$ & $.122^{* * * *}$ & .046 & 1 & \\
\hline & $\mathrm{p}$ & .805 & .000 & .010 & .006 & .000 & .019 & .012 & .351 & & \\
\hline & $\mathrm{N}$ & 421 & 421 & 421 & 421 & 421 & 421 & 421 & 421 & 421 & \\
\hline \multirow{3}{*}{$\begin{array}{l}\text { Total } \\
\text { Motivation }{ }^{10}\end{array}$} & $\mathrm{r}$ & $.375^{* *}$ & $.110^{*}$ & $.316^{* *}$ & $.844^{* * *}$ & $.668^{* * *}$ & $.870^{* * * *}$ & $.763^{* *}$ & $.861^{* * *}$ & $.359^{* *}$ & 1 \\
\hline & $\mathrm{p}$ & .000 & .024 & .000 & .000 & .000 & .000 & .000 & .000 & .000 & \\
\hline & $\mathrm{N}$ & 421 & 421 & 421 & 421 & 421 & 421 & 421 & 421 & 421 & 421 \\
\hline
\end{tabular}

When Table 2 is examined, although there is a strong positive relation between flexibility feature and internal goal arranging $(r=, 425 \mathrm{p}=, 000)$, external goal arranging $(\mathrm{r}=, 140 \mathrm{p}=, 004)$, task value $(\mathrm{r}=, 425 \mathrm{p}=, 000)$, belief of control on learning $(r=, 301 \mathrm{p}=, 009)$, features about learning and performance $(r=, 371 \mathrm{p}=, 000)$, total motivation $(\mathrm{r}=, 375$ $\mathrm{p}=, 000)$, there is no significant relation between exam anxiety $(\mathrm{r}=, 012 \mathrm{p}=, 805)$.

While there is a high positive relation between accepting the uncertainty and exam anxiety ( $r=, 216 \mathrm{p}=, 000)$, there is a low relation with internal goal arranging $(\mathrm{r}=, 096 \mathrm{p}=, 050)$, features about learning and performance $(\mathrm{r}=, 087 \mathrm{p}=, 073)$ and total motivation. No significant relation between sub-dimensions of motivation feature and accepting the uncertainty can be found.

Although there is a high positive relation between total score of curiosity and exploring and internal goal arranging $(\mathrm{r}=, 343 \mathrm{p}=, 000)$, task value $(\mathrm{r}=, 280 \mathrm{p}=, 000)$, belief of control on learning $(\mathrm{r}=, 206 \mathrm{p}=, 000)$, features about learning 
and performance $(\mathrm{r}=, 301 \mathrm{p}=, 000)$, total motivation $(\mathrm{r}=, 316 \mathrm{p}=, 000)$, there is a low positive relation with external goal arranging $(\mathrm{r}=, 105 \mathrm{p}=, 031)$ and exam anxiety $(\mathrm{r}=, 126 \mathrm{p}=, 010)$.

Table 4. Correlation Coefficient between Curiosity and Exploring Levels and Learning Strategies of Students

\begin{tabular}{|c|c|c|c|c|c|c|c|c|c|c|c|c|c|c|}
\hline & & 1 & 2 & 3 & 4 & 5 & 6 & 7 & 8 & 9 & 10 & 11 & 12 & 13 \\
\hline \multirow{3}{*}{ Flexibility $^{1}$} & $\mathrm{r}$ & 1 & & & & & & & & & & & & \\
\hline & $\mathrm{p}$ & & & & & & & & & & & & & \\
\hline & $\mathrm{N}$ & 421 & & & & & & & & & & & & \\
\hline \multirow{3}{*}{$\begin{array}{l}\text { Accepting the } \\
\text { Uncertainty }^{2}\end{array}$} & $\mathrm{r}$ & $.316^{* *}$ & 1 & & & & & & & & & & & \\
\hline & $\mathrm{p}$ & .000 & & & & & & & & & & & & \\
\hline & $\mathrm{N}$ & 421 & 421 & & & & & & & & & & & \\
\hline \multirow{3}{*}{$\begin{array}{l}\text { Total Curiosity and } \\
\text { Exploring }^{3}\end{array}$} & $r$ & $.856^{* *}$ & $.761^{* *}$ & 1 & & & & & & & & & & \\
\hline & $\mathrm{p}$ & .000 & .000 & & & & & & & & & & & \\
\hline & $\mathrm{N}$ & 421 & 421 & 421 & & & & & & & & & & \\
\hline \multirow{3}{*}{ Repetition $^{4}$} & $\mathrm{r}$ & $.314^{* *}$ & .022 & $.227^{* *}$ & 1 & & & & & & & & & \\
\hline & $\mathrm{p}$ & .000 & .652 & .000 & & & & & & & & & & \\
\hline & $\mathrm{N}$ & 421 & 421 & 421 & 421 & & & & & & & & & \\
\hline \multirow{3}{*}{ Regulation $^{5}$} & $\mathrm{r}$ & $.343^{* *}$ & .062 & $.268^{* *}$ & $.674^{* *}$ & 1 & & & & & & & & \\
\hline & $\mathrm{p}$ & .000 & .206 & .000 & .000 & & & & & & & & & \\
\hline & $\mathrm{N}$ & 421 & 421 & 421 & 421 & 421 & & & & & & & & \\
\hline \multirow{3}{*}{ Explication $^{6}$} & $\mathrm{r}$ & $.383^{* *}$ & .078 & $.305^{* *}$ & $.656^{* *}$ & $.737^{* *}$ & 1 & & & & & & & \\
\hline & $\mathrm{p}$ & .000 & .110 & .000 & .000 & .000 & & & & & & & & \\
\hline & $\mathrm{N}$ & 421 & 421 & 421 & 421 & 421 & 421 & & & & & & & \\
\hline \multirow{3}{*}{ Critical Thinking ${ }^{7}$} & $\mathrm{r}$ & $.393^{* *}$ & $.142^{*}$ & $.347^{* *}$ & $.675^{* *}$ & $.725^{* *}$ & $.715^{* *}$ & 1 & & & & & & \\
\hline & $\mathrm{p}$ & .000 & .003 & .000 & .000 & .000 & .000 & & & & & & & \\
\hline & $\mathrm{N}$ & 421 & 421 & 421 & 421 & 421 & 421 & 421 & & & & & & \\
\hline \multirow{3}{*}{ Seek for Help ${ }^{8}$} & $\mathrm{r}$ & $.245^{* *}$ & $.117^{*}$ & $.231^{* *}$ & $.506^{* *}$ & $.464^{* *}$ & $.604^{* *}$ & $.559^{* *}$ & 1 & & & & & \\
\hline & $\mathrm{p}$ & .000 & .017 & .000 & .000 & .000 & .000 & .000 & & & & & & \\
\hline & $\mathrm{N}$ & 421 & 421 & 421 & 421 & 421 & 421 & 421 & 421 & & & & & \\
\hline \multirow{4}{*}{ Peer Collaboration ${ }^{9}$} & $\mathrm{r}$ & $.174^{* *}$ & $.162^{* *}$ & $.207^{* *}$ & $.433^{* *}$ & $.407^{* *}$ & $.484^{* *}$ & $.484^{* *}$ & $.513^{* *}$ & 1 & & & & \\
\hline & $\mathrm{p}$ & .000 & .001 & .000 & .000 & .000 & .000 & .000 & .000 & & & & & \\
\hline & $\mathrm{N}$ & 421 & 421 & 421 & 421 & 421 & 421 & 421 & 421 & 421 & & & & \\
\hline & $\mathrm{r}$ & $.359^{* *}$ & .091 & $.295^{* *}$ & $.749^{* *}$ & $.750^{* *}$ & $.780^{* *}$ & $.742^{* *}$ & $.625^{* *}$ & $.502^{* *}$ & 1 & & & \\
\hline \multirow{2}{*}{ Meta Cognitive $^{10}$} & $\mathrm{p}$ & .000 & .062 & .000 & .000 & .000 & .000 & .000 & .000 & .000 & & & & \\
\hline & $\mathrm{N}$ & 421 & 421 & 421 & 421 & 421 & 421 & 421 & 421 & 421 & 421 & & & \\
\hline \multirow{4}{*}{$\begin{array}{l}\text { Effort } \\
\text { Management }{ }^{11}\end{array}$} & $\mathrm{r}$ & $.096^{*}$ & $.245^{* *}$ & $.199^{* *}$ & $.270^{* *}$ & $.290^{* *}$ & $.401^{* *}$ & $.397^{* *}$ & $.572^{* *}$ & $.356^{* *}$ & $.420^{* *}$ & 1 & & \\
\hline & $\mathrm{p}$ & .009 & .000 & .000 & .000 & .000 & .000 & .000 & .000 & .000 & .000 & & & \\
\hline & $\mathrm{N}$ & 421 & 421 & 421 & 421 & 421 & 421 & 421 & 421 & 421 & 421 & 421 & & \\
\hline & $\mathrm{r}$ & $.220^{* *}$ & $.116^{*}$ & $.213^{* *}$ & $.549^{* *}$ & $.530^{* *}$ & $.674^{* *}$ & $.566^{* *}$ & $.635^{* *}$ & $.462^{* *}$ & $.649^{* *}$ & $.588^{* *}$ & 1 & \\
\hline Time and Studying & $\mathrm{p}$ & .000 & .017 & .000 & .000 & .000 & .000 & .000 & .000 & .000 & .000 & .000 & & \\
\hline Environment ${ }^{12}$ & $\mathrm{~N}$ & 421 & 421 & 421 & 421 & 421 & 421 & 421 & 421 & 421 & 421 & 421 & 421 & \\
\hline \multirow{3}{*}{$\begin{array}{l}\text { Total Learning } \\
\text { Strategies }^{13}\end{array}$} & $\mathrm{r}$ & $.368^{* *}$ & $.136^{* *}$ & $.326^{* *}$ & $.789^{* *}$ & $.801^{* *}$ & $.874^{* *}$ & $.835^{* *}$ & $.761^{* *}$ & $.629^{* *}$ & $.916^{* *}$ & $.582^{* *}$ & $.809^{* *}$ & 1 \\
\hline & $\mathrm{p}$ & .000 & .005 & .000 & .000 & .000 & .000 & .000 & .000 & .000 & .000 & .000 & .000 & \\
\hline & $\mathrm{N}$ & 421 & 421 & 421 & 421 & 421 & 421 & 421 & 421 & 421 & 421 & 421 & 421 & 421 \\
\hline
\end{tabular}

When Table 4 is examined high positive relation is found between flexibility and repetition $(\mathrm{r}=, 314 \mathrm{p}=, 000)$, regulation $(\mathrm{r}=, 343 \mathrm{p}=, 000)$, explication $(\mathrm{r}=, 383 \mathrm{p}=, 000)$, critical thinking $(\mathrm{r}=, 393 \mathrm{p}=, 000)$, seek for help $(\mathrm{r}=, 245$ $\mathrm{p}=, 000)$, peer collaboration $(\mathrm{r}=, 174 \mathrm{p}=, 000)$, meta cognitive $(\mathrm{r}=, 359 \mathrm{p}=, 000)$, effort management $(\mathrm{r}=, 096 \mathrm{p}=, 0049)$, sub dimensions of time and working environment $(\mathrm{r}=, 220 \mathrm{p}=, 000)$ and total of learning strategies $(\mathrm{r}=, 368 \mathrm{p}=, 000)$.

Likewise high positive relation is found between total of curiosity and exploring and repetition $(\mathrm{r}=, 227 \mathrm{p}=, 000)$, regulation $(\mathrm{r}=, 268 \mathrm{p}=, 000)$, explication $(\mathrm{r}=, 305 \mathrm{p}=, 000)$, critical thinking $(\mathrm{r}=, 347 \mathrm{p}=, 000)$, seek for help $(\mathrm{r}=, 231$ $\mathrm{p}=, 000)$, peer collaboration $(\mathrm{r}=, 207 \mathrm{p}=, 000)$, meta cognitive $(\mathrm{r}=, 295 \mathrm{p}=, 000)$, effort management $(\mathrm{r}=, 199 \mathrm{p}=, 009)$, sub dimensions of time and studying environment $(\mathrm{r}=, 213 \mathrm{p}=, 000)$ and total of learning strategies $(\mathrm{r}=, 326 \mathrm{p}=, 000)$. 
On the other hand, while there is a high positive relation between accepting the uncertainty and critical thinking $(\mathrm{r}=, 142 \mathrm{p}=, 003)$, peer collaboration $(\mathrm{r}=, 162 \mathrm{p}=, 001)$, effort management $(\mathrm{r}=, 245 \mathrm{p}=, 000)$ and total of learning strategies $(r=, 136 \mathrm{p}=, 000)$, low positive relation with seek for help $(\mathrm{r}=, 117 \mathrm{p}=, 017)$, metacognitive $(\mathrm{r}=, 091 \mathrm{p}=, 062)$ and features of time and studying environment is found. No significant relation is determined between accepting the uncertainty and other sub-dimensions of learning strategies.

Table 5. Regression Table for Predicting the Motivation Level of Curiosity and Exploring Levels

\begin{tabular}{|c|c|c|c|c|c|c|c|c|}
\hline $\begin{array}{l}\text { Curiosity } \\
\text { and } \\
\text { Exploring }\end{array}$ & & $\boldsymbol{\beta}$ & $\mathbf{t}$ & $p$ & $\boldsymbol{R}$ & $R^{2}$ & $\mathbf{F}$ & $\mathbf{P}$ \\
\hline \multirow{8}{*}{ 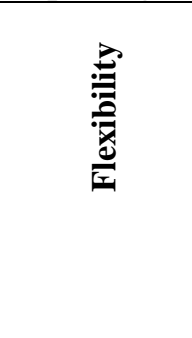 } & Motivation & & & & .445 & .019 & 10.040 & .000 \\
\hline & Internal Goal Arranging & 257 & 2.654 & .008 & & & & \\
\hline & External Goal Arranging & -.168 & -2.197 & .029 & & & & \\
\hline & Task Value & -.026 & -.222 & .825 & & & & \\
\hline & Belief of Control on Learning & -.044 & -.567 & .571 & & & & \\
\hline & Exam Anxiety & -.104 & -1.623 & .105 & & & & \\
\hline & Learning and Performance Features & .118 & 1.557 & .120 & & & & \\
\hline & Motivation & & & & .265 & .070 & 5.204 & .000 \\
\hline \multirow{7}{*}{ 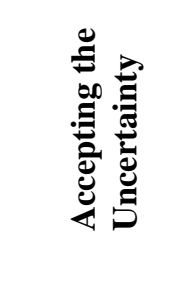 } & Internal Goal Arranging & .031 & .298 & .766 & & & & \\
\hline & External Goal Arranging & -.185 & -2.237 & .026 & & & & \\
\hline & Task Value & -.177 & -1.389 & .166 & & & & \\
\hline & Belief of Control on Learning & -.193 & -2.330 & .020 & & & & \\
\hline & Exam Anxiety & .135 & 1.966 & .050 & & & & \\
\hline & Learning and Performance Features & -.058 & -.298 & .048 & & & & \\
\hline & Motivation & & & & .376 & .015 & 11.376 & .000 \\
\hline \multirow{6}{*}{ 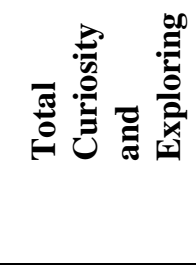 } & Internal Goal Arranging & .193 & 1.922 & .055 & & & & \\
\hline & External Goal Arranging & -.216 & -2.721 & .007 & & & & \\
\hline & Task Value & -.115 & -.935 & .350 & & & & \\
\hline & Belief of Control on Learning & -.135 & -1.698 & .090 & & & & \\
\hline & Exam Anxiety & .003 & .045 & .964 & & & & \\
\hline & Learning and Performance Features & -.352 & -1.922 & .055 & & & & \\
\hline
\end{tabular}

$\mathrm{F}(6,414)$

When Table 5 is examined the model between flexibility and motivation presents significant relation. When $\mathrm{t}-$ test results about $(\mathrm{R}=, 445 \mathrm{R} 2=, 019 ; \mathrm{p}<.001)$ regression coefficient is examined, 'internal goal arranging $(\mathrm{t}=2,654 \mathrm{p}$ $=.008)$, external goal arranging $(\mathrm{t}=-2,197 \mathrm{p}=.029)^{\prime}$ ' flexibility features are predicting motivation feature and it is seen that it explains $\% 19$ of total variance $\mathrm{F}(6,414)=10,040 \mathrm{p}<.005)$.

The model between accepting the uncertainty and motivation presents significant relation. When t- test results about ( $\mathrm{R}=, 265 \mathrm{R} 2=, 070$; $\mathrm{p}<.001)$ regression coefficient is examined, 'external goal arranging ( $\mathrm{t}=-2,237 \mathrm{p}=.026$ ), belief of control about learning ( $\mathrm{t}=-2,330 \mathrm{p}=.020)$, exam anxiety $(\mathrm{t}=1,966 \mathrm{p}=.050)$, features about learning and performance $(\mathrm{t}=-, 298 \mathrm{p}=.048)^{\prime}$ accepting the uncertainty features are predicting motivation feature and it is seen that it explains $\% 70$ of total variance $\mathrm{F}(6,414)=5,204 \mathrm{p}<.005)$.

The model between curiosity and exploring and motivation presents significant relation. When t- test results about $(\mathrm{R}=, 376 \mathrm{R} 2=, 015 ; \mathrm{p}<.001)$ regression coefficient is examined, 'internal goal arranging ( $\mathrm{t}=1,922 \mathrm{p}=.055)$, external goal arranging $(\mathrm{t}=-2,721 \mathrm{p}=.007)$, features about learning and performance $(\mathrm{t}=-1,922 \mathrm{p}=.055)^{\prime}$ ' curiosity and exploring features are predicting motivation feature and it is seen that it explains $\% 15$ of total variance $\mathrm{F}(6,414)=$ $11,376 \mathrm{p}<.005)$. 
Table 6. Regression Table for Predicting the Learning Strategies of Curiosity and Exploring Levels

\begin{tabular}{|c|c|c|c|c|c|c|c|c|}
\hline $\begin{array}{l}\text { Curiosity } \\
\text { and } \\
\text { Exploring }\end{array}$ & & $\boldsymbol{\beta}$ & $\mathbf{t}$ & $p$ & $\boldsymbol{R}$ & $\boldsymbol{R}^{2}$ & $\mathbf{F}$ & $\mathbf{P}$ \\
\hline \multirow{10}{*}{ 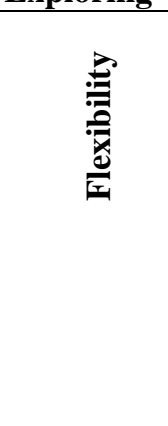 } & Learning Strategies & & & & .438 & .019 & 10.810 & .000 \\
\hline & Repetition & .004 & .053 & .958 & & & & \\
\hline & Regulation & .001 & .013 & .990 & & & & \\
\hline & Explication & .228 & 2.736 & .006 & & & & \\
\hline & Critical Thinking & .249 & 3.267 & .001 & & & & \\
\hline & Seek for Help & .044 & .650 & .516 & & & & \\
\hline & Peer Collaboration & -.053 & -.975 & .330 & & & & \\
\hline & Meta Cognitive & .083 & .907 & .365 & & & & \\
\hline & Effort Management & -.088 & -1.478 & .140 & & & & \\
\hline & Time and Studying Environment & -.083 & -1.166 & .244 & & & & \\
\hline \multirow{10}{*}{ 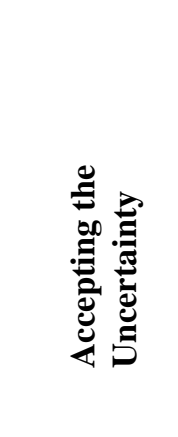 } & Learning Strategies & & & & .292 & .075 & 4.252 & .000 \\
\hline & Repetition & -.115 & -1.507 & .133 & & & & \\
\hline & Regulation & -.022 & -.270 & .788 & & & & \\
\hline & Explication & -.050 & -.562 & .574 & & & & \\
\hline & Critical Thinking & .163 & 2.013 & .045 & & & & \\
\hline & Seek for Help & -.063 & -.876 & .381 & & & & \\
\hline & Peer Collaboration & .122 & 2.097 & .037 & & & & \\
\hline & Meta Cognitive & .009 & .097 & .923 & & & & \\
\hline & Effort Management & .248 & 3.925 & .000 & & & & \\
\hline & Time and Studying Environment & -.036 & -.469 & .639 & & & & \\
\hline \multirow{8}{*}{ 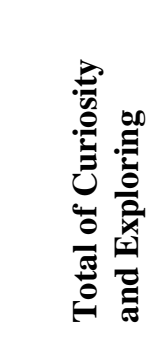 } & Learning Strategies & & & & .385 & .015 & 7.125 & .000 \\
\hline & Repetition & -.087 & -1.171 & .242 & & & & \\
\hline & Regulation & -.034 & -.427 & .670 & & & & \\
\hline & Explication & .116 & 1.349 & .178 & & & & \\
\hline & Critical Thinking & .246 & 3.138 & .002 & & & & \\
\hline & Seek for Help & -.030 & -.425 & .671 & & & & \\
\hline & Peer Collaboration & .027 & .480 & .632 & & & & \\
\hline & Meta Cognitive & .012 & .128 & .898 & & & & \\
\hline
\end{tabular}

$\mathrm{F}(10,410)$

When Table 6 is examined the model between flexibility and learning strategies presents significant relation. When ttest results about $(\mathrm{R}=, 438 \mathrm{R} 2=, 019$; $\mathrm{p}<.001)$ regression coefficient is examined, 'explication $(\mathrm{t}=2,736 \mathrm{p}=.006)$, critical thinking ( $\mathrm{t}=3,267 \mathrm{p}=.001$ )' flexibility features are predicting learning strategies feature and it is seen that it explains $\% 19$ of total variance $F(10,410)=10,810 \mathrm{p}<.005)$.

The model between accepting the uncertainty and learning strategies presents significant relation. When $\mathrm{t}-$ test results about $(\mathrm{R}=, 292 \mathrm{R} 2=, 075 ; \mathrm{p}<.001)$ regression coefficient is examined, 'critical thinking, peer collaboration, effort management' accepting the uncertainty features are predicting learning strategy and it is seen that it explains \%75 of total variance $\mathrm{F}(10,410)=4,252 \mathrm{p}<.005)$.

The model between accepting the uncertainty and learning strategies presents significant relation. When $\mathrm{t}$ - test results about $(\mathrm{R}=, 385 \mathrm{R} 2=, 015 ; \mathrm{p}<.001)$ regression coefficient is examined, 'critical thinking $(\mathrm{t}=3,138 \mathrm{p}=.002)$ ' curiosity and exploring features are predicting learning strategies feature and it explains $\% 15$ of the total variance. $\mathrm{F}_{(10,410)}=$ $4,252 \mathrm{p}<.005)$.

\section{Discussion and Conclusions}

In this study, a significant relation is determined between accepting the uncertainty sub feature and general curiosity and exploring feature and motivation level which reflects the desire to explore the new, uncertain and unpredictable things of daily life with flexibility sub-dimension which is the motivation for seeking knowledge and new experience. It is seen that the level of motivation increases with the increase of both, the sub-dimensions flexibility and acceptance of uncertainty, and the general feeling of curiosity and discovery. While flexibility feature predicts $\% 19$ 
of variance and accepting the uncertainty predicts $\% 70$, general curiosity and exploring predicts $\% 15$ of variance. In a study applied to students, Özçalışan (2012) determined that high level of curiosity and exploring level help students to gather their attention and pull into the lesson. In effective learning and teaching book, Açıkgöz (2009) suggests students to be involved in learning process and to be felt effective by increasing motivation and choosing new assignments with raising curiosity in students. In their book, Eggen and Kauchak (1994), state that personal factors such as curiosity, awareness, and worrying play an important role and teachers can motivate students by using dilemmas and raising curiosity in students. In a study Criss (2011) conducted on students, he stated that an effective teacher can create motivation by building relations with students and encouraging affective domain. Turan et al. (2012) examined the curiosity levels of university students who are studying in various departments in their studies and determined that it is higher than average scale score. As it can be understood from the sources, it is thought that curiosity and exploring feeling has a triggering and an incentive feature. Curiosity, knowing and researching feelings that come from within can provide achievement motive to mobilize by raising interest and excitement although the result is unclear. It is thought that the idea of physical education and sports teacher candidates' desire for curiosity and exploring motivation tendency can be effective, shows similarities with the body of literature.

On the other hand, it is determined that there is a significant relationship between usage of learning strategies and flexibility, accepting the uncertainty, general curiosity and exploring the situation. While flexibility feature \% 19 , accepting the uncertain predict $\% 75$ of variance, the total score of curiosity and exploring feature predicts $\% 51$ of variance. When sub-dimensions are examined, the relation between effort management and critical thinking and curiosity and exploring features is found stronger. Even though there is not sufficient work on the effect of physical education teacher candidates' curiosity and exploring levels on learning strategies in literature, Turan (2015) has found a significant relation between curiosity and learning strategies in his study on 130 university students. Deringöl et al. (2010) has found elementary education teacher candidates' curiosity level higher than average scale score in their studies. Bahadır and Certel (2012) have found in their studies on curiosity levels of physical education and sports teachers' that total score of curiosity is higher than the findings that are acquired by the body of literature studies and average curiosity score. Sang-Jan (1993) examined the relation of academic success in some of his students' usage of learning strategy and their attitude towards learning process and it is revealed that successful students in the study are more interested (curious), use more effective strategies and their academic motivation is higher than those who are less successful. In a study that was conducted by Yıldırım and Somuncuoğlu (1998), the close relation of strategy usage should be emphasized with problems or genuine learning activities in strategy usage training and teaching-learning process should be performed as part of critical thinking/ problem-solving skills. When our research is examined, it is determined that as physical education teacher candidate students' curiosity and exploring levels increase, their usage of learning strategies increase as well. Physical education teachers' lessons towards their profession during university (strategy development, material planning, teaching principals and methods etc.) are also thought to affect the learning strategies usage levels because of frequent dealing with uncertain situations, planning the next move, predicting opponent's next move in sports which involves curiosity and strategy at the same time.

When our study is examined, just as curiosity and exploring effect many fields it also affects motivation and learning strategies' usage. Curiosity and exploring have predicted the $\% 15$ of motivation and learning strategies usage. For this reason, genuine environments which triggers the curiosity of students should be created while preparing the education program, especially in schools that train teachers.

\section{Suggestions}

a) While teaching, encouraging stimuli (money, promotion, service points, etc.) should be used to raise curiosity, stimulate, and encourage the use of strategy.

b) In order to raise students' academic success, instructors and lecturers who work in universities should make lessons more interesting so as to raise students' curiosity levels.

c) Educators should prefer teaching methods that raise curiosity in students.

d) Proper environments in universities should be created for students to easily access whatever they are curious about.

e) Curiosity levels of students who study in Physical Education and Sports Teacher Department should be determined and new studies should be done in order to raise this level. 
f) During teacher internship programs, motivation and learning strategies usage should be encouraged and in-service training should be given which raise curiosity about the subject.

g) During students' university education, more lessons should take place for students to study on learning strategies and motivation.

\section{References}

Açikgöz, K. (2007). Etkili öğrenme ve öğretme. İzmir: Biliş Yayınları.

Açıkgöz, K. (2009). Etkili Öğrenme ve Öğretme (8th ed.). İzmir: Kanyılmaz Matbaası.

Akkoyunlu, B. (2008). Bilgi okuryazarlı̆̆ı ve yaşam boyu öğrenme. Sekizinci Uluslar arası Eğitim Teknolojileri Konferansı, 6-8 Mayıs 2007 Anadolu Üniversitesi, Eskişehir. 11-15.

Bahadır Z., \& Certel Z. A. (2012). Research on Curiosity Levels of Physical Education and Sports Teachers, (Kayseri Province Sample). Niğde Üniversitesi Beden Eğitimi Ve Spor Bilimleri Dergisi, 3, 340-348.

Büyüköztürk, Ş., Akgün, Ö. E., Özkahveci, Ö., \& Demirel, F. (2004). Güdülenme ve öğrenme stratejileri ölçeğinin Türkçe formunun geçerlik ve güvenirlik çalışması. Kuram ve Uygulamada Eğitim Bilimleri, 4(2), 207-239.

Criss E. (2011). Motivation in Education. Music Educators Journal, 97(3), 61-66. https://doi.org/10.1177/0027432110393022

Demirel M., \& Çoşkun Diker C. (2009). Investigation of Curiosity Levels of University Students in Terms of Some Variables. Mehmet Akif Ersoy Üniversitesi Eğitim Fakültesi Dergisi, 9(18), 111-134.

Deringöl Y., Yaman Y., Özsarı İ., \& Çağırgan GD. (2010). İlköğretim Öğretmen Adaylarının Meraklıllk Düzeylerinin Incelenmesi. International Conference on New Trends in Education and Their Implications, Antalya.

Eggen, P., \& Kauchak, D. (1994). Educational Psychology Classroom Connections (2nd ed.). USA: Macmillan Publishing Company.

Eren, A. (2009). Bilgi kaynaklı merak ve başarı amaçları arasındaki ilişkinin incelenmesi. Eurasian Journal of Educational Research, 36, 129-144.

Garcia, T., \& Pintrich, P.R. (1996). Assessing Students' Motivation and Learning Strategies in the Classroom Context: the Motivated Strategies for Learning Questionnaire. Alternatives in assessment of achievements, learning processes and prior knowledge. Edited by Menucha Brenbaum, Filip JRC Dochy. Kluwer Academic Publishers. Boston/Dordrecht/London. 9-12. https://doi.org/10.1007/978-94-011-0657-3_12

Harmanlı, Z. (2000). Öğrenme Stratejileri (Etkili Öğrenme Eğitimi). İzmir: DEÜ, Buca Eğitim Fakültesi.

Karasar N. (2007). Bilimsel Araştırma Yöntemi (17th ed.). Ankara, Nobel Yayın Dağıtım: 49-53.

Kashdan, T. B., Gallagher, M. W., Silvia, P. J., Winterstein, B. P., Breen, W. E., Terhar, D.T., \& Steger, M. F. (2009). The curiosity and exploration inventory-II: Development, factor structure, and psychometrics. Journal of Research in Personality, 43, 987-998. https://doi.org/10.1016/j.jrp.2009.04.011

Keller, J. (2000). How to integrate learner motivation planning into lesson planning: the ARCS model approach. 24 Mayis 2004'te Florida State University Retrieved from www.netg.com/research/whitepapers/kellerwp.asp

McNeill, D. (1985). So you think gestures are nonverbal? Psychological Review, 92, 350-371. https://doi.org/10.1037/0033-295X.92.3.350

Naspe. (2008). National Association for Sport and Physical Education \& American Heart Association.

Özçalışan H. (2012). Yükseköğrenim Öğrencilerinin İngilizceyi Öğrenme Motivasyonları Afyon Kocatepe Üniversitesi Sosyal Bilimler Enstitüsü Eğitim Bilimleri Anabilim Dalı Yayınlanmamış Yüksek Lisans Tezi.

Sang-Jan, P. (1994). Learning strategies and attitudes of adults in a distance basic education program in Thailand and their relationship to the students' academic achievement (Doctoral dissertation, University of Oregon, 1993). Dissertation Abstracts International, 54(9), 3409A.

Selçuk, Z. (1999). Gelişim ve ögrenme. Altıncı baskı. Ankara: Nobel Yayınları.113-115.

Silvia, P. J. (2008a). Appraisal components and emotion traits: Examining the appraisal basisof trait curiosity. Cognition and Emotion, 22, 94-113. https://doi.org/10.1080/02699930701298481 
Somuncuoglu Y., \& Yıldırım A. (1998). Öğrenme Stratejileri: Teorik Boyutları Araştırma Bulguları ve Uygulama İçin Ortaya Koyduğu Sonuçlar. Eğitim ve Bilim Dergisi, 20, 110.

Stipek, D. (1998). Motivation to learn, from theory to practice. Massachusetts: A Viacom Company.

Turan M. B. (2015). Beden Eğitimi ve Spor Öğretmenliği Bölümünde Öğrenim Gören Öğrencilerin Meraklllı Düzeyleri İle Öğrenme Stilleri Arasındaki İlişkinin Incelenmesi. Erciyes Üniversitesi Sağlık Bilimleri Enstitüsü Yayınlanmamış Yüksek Lisans Tezi.

Ünlü, H., Sünbül, M., \& Aydos, L. (2008). Beden Eğitimi Öğretmenleri Yeterlik Ölçeği: Geçerlilik ve Güvenirlik Çalışması. Kırşehir Ĕ̈itim Fakültesi Dergisi, 9(2), 23-33.

Warren, A. (2000). Factors affecting the motivation of online learners. Center for learning and teaching, niversity of Southampton. Retrieved 24 Mayis 2004 from www.clt.soton.ac.uk/adam/motivationppd

Yaylacı F. (2012). İlköğretim Okullarında Nasıl bir Beden Eğitimi Dersi istiyorum? Milli eğitim Dergisi, 195, 194-209. 